UDC 657.8:004

JEL Classification: M41, M42, D24

DOI: 10.15587/2706-5448.2021.238858

Article type «Original research»

\section{Nataliia Pochynok, Volodymyr Muravskyi, Volodymyr Farion}

\title{
IMPLEMENTATION OF ELECTRONIC COMMUNICATIONS IN ACCOUNTING OF PUBLIC PROCUREMENT
}

The object of research is the public procurement system in terms of accounting for the processes of buying (selling) goods (works, services) using electronic communications. A problematic aspect of modern electronic public procurement platforms is the lack of information support for accounting, control and taxation functions. In the context of the development of innovative computer and communication technologies, it becomes possible to integrate various electronic services and electronic communications into the public procurement system in order to automate accounting processes.

In the process of studying the prospects for the implementation of a system of public communications with expanded functional capabilities, general scientific empirical, logical and historical methodological methods of cognition of reality were used. The theoretical and methodological aspects of improving the accounting of public procurement in the context of the formation of an innovative electronic platform for business communications were studied on the basis of institutional and innovative methods of scientific research.

The paper proposes to place electronic contracts at the heart of the business communications system. A procedure has been developed for business interaction between participants in electronic trading through the mechanism for concluding and executing electronic contracts for the purchase (sale) of goods (works, services). Based on the creation of a system of electronic contracts, it is possible to form a database of credentials. The expediency of using accounting information for the automated implementation of public procurement accounting procedures has been substantiated. The methodology for accounting for the occurrence and repayment of accounts payable and receivable for purchased (sold) goods (works, services), charging and paying taxes and fees, electronic money transactions in various currencies, electronic money and cryptocurrency, the occurrence of credit obligations, calculating the amount of bad debts has been improved.

The implementation of a public procurement system with expanded functionality will facilitate the establishment of effective business communications with contractors, the integration of disparate electronic services into a single system. As well as minimizing costs in the process of electronic trading, automating the processing of primary information, optimizing accounting and management processes at the enterprise.

Keywords: public procurement, electronic communications, accounting automation, accounting information, electronic trading.

\section{How to cite}

Pochynok, N., Muravskyi, V., Farion, V. (2021). Implementation of electronic communications in accounting of public procurement. Technology Audit and Production Reserves, 4 (4 (60)), 6-10. doi: http://doi.org/10.15587/2706-5448.2021.238858

\section{Introduction}

The development of the latest computer and communication technologies has contributed to the formation of a system of electronic communications that unite business entities to achieve a common socio-economic goal. With the help of the electronic communications system, the implementation of business interaction of business entities takes place. Business communications in electronic form ensure the optimization of material and financial resources and working hours of accounting and management personnel. The most effective means of optimizing the costs of enterprises, especially those of state ownership or managers of budgetary funds, is the organization of electronic public procurement platforms.

The implementation of the public procurement system ensures: minimizing the cost of purchasing goods (works, services), optimizing market competition, preventing corruption components of tender procedures, finding reliable partners in the implementation of business processes, and the like. The benefits of public procurement have become possible through the integration of electronic communications with various institutions and electronic services. The level of penetration of modern electronic communications 
in the public procurement system determines the success of reforms in the implementation of electronic tenders. Therefore, research on expanding the functional characteristics of public procurement sites through the introduction of additional electronic communications is relevant.

\section{The object of research and its technological audit}

The object of research is the public procurement system in terms of accounting for the processes of buying (selling) goods (works, services) using electronic communications. A problematic aspect of modern electronic public procurement platforms is the lack of information support for accounting, control and taxation functions. In the context of the development of innovative computer and communication technologies, it becomes possible to integrate various electronic services and electronic communications into a single system of public procurement. A promising direction for expanding the functionality of the public procurement system is information synchronization through electronic communications channels with specialized software for the purposes of accounting automation. Through information exchange between electronic trading and accounting systems, it is possible to form a unique business communication environment with the functions of automated accounting, control and management of economic processes. The need to increase the functionality of the electronic trading system through the implementation of additional electronic services and communications determines the aim of research.

\section{The aim and objectives of research}

The aim of research is to study the prospects for improving the accounting of public procurement in the context of the implementation of electronic communications. To implement the formed aim, the following objectives must be identified:

1. Justify the feasibility of expanding the functionality of the public procurement system based on the formation of electronic contracts with counterparties.

2. Develop a procedure for integrating electronic services and electronic communications into the public procurement system to improve the methodology for automating accounting processes at the enterprise.

\section{Research of existing solution to the problem}

The prospect of a functional combination of various electronic services and electronic communications between buyers and sellers of goods (works, services) is the subject of scientific research for many scientists. For example, the author of work [1] proves that for the purposes of forming an electronic platform for business communications, it is necessary:

- create an information base of accounts payable and receivable of settlement participants;

- check in electronic form mutual claims and obligations and find the most rational ways to repay mutual debts; - carry out offsets, gradually reducing the amount of debt [1].
Also in work [2] it is proved that modern accounting computer programs allow to control contracted debt repayment terms in order to prevent violations of the terms of contracts. On the other hand, according to the author of [3], non-compliance with payment discipline by debtors, untimely filing of claims on accounts receivable can lead to a decrease in the volume of highly liquid working capital, and, consequently, to a violation of the financial stability of the enterprise. The use of a system of electronic banking communications additionally contributes to the growth of the level of control over settlement transactions in the process of repayment of accounts receivable [4]. The authors of [5] propose to consider the relationship with debtors and creditors in a single complex, which provides a manifestation of a synergistic effect in the control of settlements with counterparties.

The problems of information support of the communication system of relationships are diversified in work [6]. The team of authors of work [7] proved the influence of online communications with counterparties on the formation of additional company value. Similarly, the authors of [8], when forming a global information system, discovered the problem of structuring a large amount of information about counterparties. Scientists have proposed to accumulate data in a block-chain (blockchain) structure to provide quick access and prevent information loss [8]. In the context of updating the blockchain technology in [9], a methodology for controlling electronic transactions between counterparties was developed and it was proposed to create a global information system of electronic communications based on blockchain technology in order to ensure reliability, confidentiality, efficiency and data protection. The study [10] developed a method for identifying and authorizing parties to contractual relations in the system of business communications for the formation of large amounts of information.

The author of [11] assigns the leading role in the formation of large information systems of business communications to Big Data technologies. The author of [12] considers communication platforms as an interface that combines information processing technologies with information systems and participants in the communication process. In [13], the global nature and internationality of the formation and use of integrated information systems based on large data bases is additionally emphasized. On the basis of generalizing the prospects for using the latest technologies in organizing business communications, the authors of [14] identified the risks of information exchange with counterparties, and requires improving the management system, accounting, analysis and control of information processes.

Despite significant scientific developments in the field of electronic communications between the parties to contractual relations, the accounting and management aspects of the functioning of joint electronic trading platforms remain without attention. Among them, an important social place is occupied by the system of public procurement of state enterprises and budget funds managers.

\section{Methods of research}

To achieve the current aim of scientific research, an institutional approach was used and, in particular, the concept of institutional changes to substantiate the feasibility 
of expanding the functionality of the public procurement system through the integration of additional electronic services and electronic communications. The institutional approach to the theoretical and methodological foundations of accounting is based on the idea of its important socio-economic role and importance for optimizing the costs of an enterprise, including state-owned institutions or managers of budgetary funds. An innovative approach is used to reveal the prospects for the implementation of the latest computer and communication technologies in the financial, economic and accounting processes at the enterprise.

A hypothesis has been formed about the feasibility of transforming the electronic public procurement system into a unique platform for business communications for all business entities, regardless of the form of ownership and size of the business, which combines all participants in contractual relations with the ability to automate the accounting of a complex of economic processes.

\section{Research results}

The electronic public procurement platform provides business relationships between buyers and suppliers of goods (works, services). It is advisable to expand the communication capabilities of the public procurement system in the direction of increasing the number of business services. First of all, it is advisable to provide for the implementation of business communications between counterparties. Buyers and suppliers can communicate through the public procurement system, select reliable partners, look for proposals on the principles of co-financing or crediting, and the like.

In addition to the traditional list of data identifying business entities in the public procurement system, it is advisable to provide for the possibility of checking business reputation following the example of the Youcontrol service. Before starting to formalize business relationships, it is important to check the history of the counterparty's functioning in legal, judicial, fiscal, banking databases. If doubts arise about the good faith of the counterparty, a decision may be made to refuse to cooperate with it (exclusion from tender procedures). If the company's management decides to continue business cooperation with counterparties, it is recommended to form a reserve of doubtful debts. Based on information about the facts and the timing of previous obligations, it is advisable to calculate the amount of contributions to the reserve fund with the aim of covering potential losses in the future. It is advisable to immediately reflect the fact of the formation of a reserve of doubtful debts in the automated accounting system.

The final stage of formalizing business communications with the selected (tender winners) counterparties is the conclusion of contracts. In the electronic system of public procurement, it is advisable to provide for the possibility of concluding electronic copies of contracts. The registration of contractual relations in electronic form is a common practice in the process of implementing socioeconomic processes in the digital economy. In particular, the operation of commodity, financial and cryptocurrency exchanges provides for the conclusion of start-up contracts without the need to draw up paper copies of contracts.
Similarly, in the provision of banking services, services are impossible without the physical presence of the client in banking or financial institutions through the execution of electronic contracts. The legal effect of electronic contracts is confirmed by digital signatures of the person authorized to formalize the contractual relationship. Registration of electronic contractual relations between participants in public procurement is useful for additional control over the spending of budget funds.

Significant advantages become available for automated accounting from parties to contractual relations. It is advisable to synchronize the electronic public procurement system with specialized software for automation of accounting. Already now, in most computer programs, electronic contracts form the basis for accounting and control of settlements with counterparties. In connection with each electronic contract, the monitoring of the occurrence and repayment of receivables and payables is carried out. Electronic communications between participants in public procurement provide automated accounting. In the event that documents appear in the automated accounting under a certain electronic contract, the sale of goods (works, services) is evidenced, it is advisable to automatically send information on the fulfillment (partial fulfillment) of contractual obligations to the electronic procurement system. After the other party of the contractual relationship has received documents on the receipt (posting) of goods (works, services) in the public procurement system, it is advisable to display the status of the completion of a certain stage or complete closure of the electronic contract.

It is advisable to integrate fiscal services into the public procurement system. First of all, the parties to the contractual relationship can check the affiliation of the counterparty to payers of VAT or other taxes and fees. In the public procurement site, it is advisable to reflect the facts of registration of tax documents for VAT on transactions of purchase and sale of goods (works, services). It is advisable for the parties to contractual relations to promptly inform about the facts of the occurrence of tax events, the need to draw up (or have already drawn up) tax invoices. Through information synchronization with accounting software, data on issued (received) tax documents can serve as the basis for automated recording of tax liabilities or a VAT tax credit.

It remains problematic in VAT accounting to determine the fact of the first event - payment (crediting) of funds or shipment (posting) of goods (works, services), which requires the integration of electronic banking communications into the public procurement system. Today, most banking or financial institutions provide for the possibility of obtaining information and disposing of funds through the communication «Client-Bank», «Internet-Bank». Clients are offered applications for cellular devices or plugins for specialized software for accounting and control of electronic money transactions.

It is advisable to provide for the function of invoicing payments for goods (works, services) and transferring funds using electronic banking communications through the public procurement platform. Counterparties can write off funds to the account of other parties to the contractual relationship immediately from the public procurement platform. In an electronic system, it is necessary to control 
documents in accordance with the rule of the first event to accurately reflect tax liabilities or VAT tax credits.

Through information synchronization in the software, for the purposes of accounting automation, it is necessary to simultaneously reflect monetary transactions. Even before receiving a bank statement in the public procurement system, it is possible to record the facts of payment for goods (work, services). Based on the data received, it is advisable to reflect the receipts or write-offs of funds in the accounting. Integration of electronic money and cryptocurrency operators into the public procurement service is promising. Without the need to visit electronic exchanges, electronic transaction aggregators, users of the public procurement platform have the opportunity to pay in various foreign currencies, digital money, cryptocurrencies.

It is also advisable to form loan offers through electronic banking communications. If the parties to the contractual relationship do not have their own funds to pay for goods (work, services) in the public procurement system, it is advisable to provide for the possibility of obtaining a loan. All banking and financial institutions, including second-hand banks, admitted to use the public procurement platform, can offer loan processing. The placement of credit offers is carried out on the principles of free competition with the execution of an electronic agreement. The user of the public procurement system selects the optimal credit conditions and receives funds to participate in public procurement. It is advisable to automatically reflect all lending operations in the automated accounting system based on the synchronized sending of data from the public procurement system. The information scheme of the extended functionality of the public procurement system, based on the implementation of electronic services and communications, is shown in Fig. 1.

So, the integration of additional electronic services into the public procurement system contributes to the formation of an integrated platform for business communications. Through electronic communication channels, information integration of the services of fiscal, banking, financial, credit and other types of institutions into the electronic trading system is possible. The expanded functioning of the public procurement platform for managers and users of budget funds can be transformed into a global communication network that unites all parties to contractual relations, regardless of the form of ownership or size of the business. Information synchronization of the public procurement system with specialized software of enterprises is the basis for automated accounting of transactions related to the registration and implementation of business relationships with counterparties.
ELECTRONIC PUBLIC PROCUREMENT SYSTEM

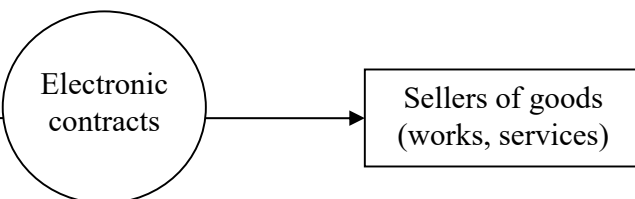

Counterparty database

Variable credentials

\section{se}

Persistent credentials

Counterparty name Solvency rating Legal and physical address

Contact and registration data Responsible persons

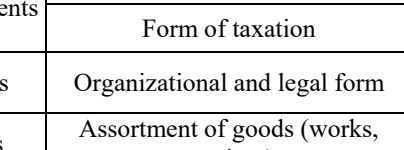
Possibility of electronic payments

\begin{tabular}{|l|c} 
Availability of tax invoices & $\begin{array}{c}\text { Assortment of good } \\
\text { services) }\end{array}$ \\
\hline
\end{tabular}
ELECTRONIC COMMUNICATIONS

\begin{tabular}{|c|c|}
\hline $\begin{array}{c}\text { Fiscal } \\
\text { institutions }\end{array}$ & $\begin{array}{c}\text { Electronic } \\
\text { business services }\end{array}$ \\
\hline
\end{tabular}

Banking institutions

AUTOMATED ACCOUNTING SYSTEM

\begin{tabular}{|c|c|}
$\begin{array}{c}\text { Taxes and fees } \\
\text { accounting }\end{array}$ & $\begin{array}{c}\text { Doubtful } \\
\text { debts } \\
\text { accounting }\end{array}$ \\
accounting \\
\hline
\end{tabular}

\section{(developed by the author)}

\section{SWOT analysis of research results}

Strengths. Strengths is in the ability to optimize information processes at enterprises, use public procurement systems in the context of expanding their functions through the implementation of various electronic services and electronic communications with fiscal, banking, financial and credit and other institutions. Information synchronization of the electronic trading system with specialized software for accounting purposes ensures fully automated processing of accounting information, transition to an exclusively electronic document flow. As well as reducing the cost of working time of accounting and management employees, accelerating information processes, reducing the cost of operating the accounting department of the enterprise.

Weaknesses. At the same time, the analysis of the shortcomings and problematic aspects of using the expanded public procurement system contributed to the identification of significant communication barriers due to the resistance to innovation of the management of budget enterprises. Since the transition exclusively to electronic auctions for the implementation of additional electronic services and electronic communications minimizes the corruption components of public procurement and leads to the publication of economic information. This may contain a fiscal interest, there is a lack of political will of the legislator in the subsequent reforms. The lack of legislative support complicates the process of implementing a public procurement system with expanded functionality.

Opportunities. A promising opportunity to use the public procurement system is its transformation into a unique 
platform for business communications for all enterprises, regardless of the form of ownership and size of the business. Such an environment for business communications ensures the transition exclusively to the electronic format for concluding and executing contracts for the purchase (sale) of goods (works, services), issuing and paying invoices in the process of electronic trading, calculating and paying taxes, and the like. These are elements of the formation of the digital economy and information society.

Threats. Since the functioning of an electronic trading system with advanced functions provides for the integration of various electronic services and electronic communications, there is a likelihood of active cyber threats of loss of accounting information. In the process of information synchronization with specialized software for the purposes of accounting automation, theft, modification, substitution, blocking, leakage of accounting information containing commercial secrets is possible. Therefore, it is important to develop effective methods of cyber protection of electronic communications at the macro and micro levels.

\section{Conclusions}

1. It is recommended to place electronic contracts at the basis of the functioning of the expanded platform for electronic public procurement. The content of the database of the system of electronic contracts was developed, which made it possible to informationally concentrate all events related to the public purchase (sale) of goods (works, services). On the basis of an electronic database, it is proposed to form a universal communication platform, contributes to the establishment of effective electronic business communications not only with parties to contractual relations, but also with banking, financial and credit, fiscal and other institutions.

2. It is proposed to use accounting information from the public procurement system to automate accounting:

- occurrence and repayment of accounts payable and receivable for purchased (sold) goods (work, services);

- accrual and payment of taxes and fees;

- electronic money transactions in various currencies,

electronic money and cryptocurrency;

- emergence of credit liabilities;

- calculating the amount of bad debts.

Implementation of the developed scheme of information synchronization of the electronic trading system with specialized software provides:

- fully automated information processing;

- transition to electronic document management;

- reducing the cost of working time of accounting and management employees;

- optimization of the functioning of the accounting department of the enterprise.

It is promising to optimize the public procurement system for government and budget managers to the level of a universal communication platform for all business entities, regardless of the form of ownership or size of business, which requires further research.

\section{References}

1. Tereshchenko, M. K. (2014). Deiaki aspekty udoskonalennia obliku, analizu ta audytu debitorskoi zaborhovanosti pidpryiemstva. Ekonomichnyi visnyk, 1, 107-113.
2. Chornak, T. V. (2010). Udoskonalennia otsinky debitorskoi zaborhovanosti ta yii vidobrazhennia u zvitnosti. Naukovyi visnyk Uzhhorodskoho natsionalnoho universytetu, 29, 56-59.

3. Koblianska, O. I. (2009). Metodolohichni aspekty obliku ta audytu debitorskoi zaborhovanosti. Visnyk Kyizskoho natsionalnoho universytetu imeni Tarasa Shevchenka, 28, 77-78.

4. Moskaliuk, H. O. (2012). Oblik ta kontrol debitorskoi zaborhovanosti: isnuiuchi problemy ta shliakhy yikh vyrishennia. Visnyk Natsionalnoho universytetu «Lvizska politekhnika», 721, 173-179. Available at: http://vlp.com.ua/node/8575

5. Zadorozhnyi,, Z.-M., Muravskyi, V., Shevchuk, O., Sudyn, Y. (2018) Management accounting of the settlements with contractors in innovative environment of business communications. Marketing and Management of Innovations, 2, 103-112. doi: http://doi.org/10.21272/ mmi.2018.2-09

6. Yakymova, L., Karielova, O. (2019). Formation of accounting and analytical information of the municipal company on accounts receivable and payable in the context of ensuring business communication. Innovative Economy, 5-6, 144-149. doi: http://doi.org/10.37332/23091533.2019.5-6.20

7. Wilkin, C. L., Campbell, J., Moore, S., Simpson, J. (2018). Creating value in online communities through governance and stakeholder engagement. International Journal of Accounting Information Systems, 30, 56-68. doi: http://doi.org/10.1016/j.accinf.2018.06.004

8. Vasarhelyi, M. A., Kogan, A., Tuttle, B. M. (2015). Big Data in Accounting: An Overview. Accounting Horizons, 29 (2), 381-396. doi: http://doi.org/10.2308/acch-51071

9. Wang, Y., Kogan, A. (2018). Designing confidentiality-preserving Blockchain-based transaction processing systems. International Journal of Accounting Information Systems, 30, 1-18. doi: http:// doi.org/10.1016/j.accinf.2018.06.001

10. Campbell, J. (2007). The Development of a B2G Online Authentication Standard: a design perspective of the policy consultation process. Australasian Journal of Information Systems, 14 (2), 81-94. doi: http://doi.org/10.3127/ajis.v14i2.471

11. Yigitbasioglu, O. (2016). Firms' information system characteristics and management accounting adaptability. International Journal of Accounting and Information Management, 24 (1), 20-37. doi: http:// doi.org/10.1108/ijaim-10-2014-0066

12. Granlund, M. (2009). On the interface between accounting and modern information technology. Turku: Uniprint, 70.

13. Nicolaou, A. I. (2011). Integrated Information Systems and Interorganizational Performance: The Role of Management Accounting Systems Design. Advances in Accounting Behavioral Research. Emerald Group Publishing Limited, 14, 117-141. doi: http://doi.org/10.1108/ s1475-1488(2011)0000014008

14. El-Ebiary, Y. A. B., Majid Alawi, N. A. (2020). The Risks of Accounting Information Systems. International Journal of Engineering Trends and Technology, 120-127. doi: http://doi.org/10.14445/22315381/ cati3p220

Nataliia Pochynok, PhD, Associate Professor, Department of Accounting and Taxation, West Ukrainian National University, Ternopil, Ukraine, ORCID: http://orcid.org/0000-0003-4416-3680

$\square$ Volodymyr Muravskyi, Doctor of Economic Science, Associate Professor, Department of Accounting and Taxation, West Ukrainian National University, Ternopil, Ukraine, e-mail:vavanm2@gmail.com, ORCID: https://orcid.org/0000-0002-6423-9059

Volodymyr Farion, PhD, Associate Professor, Department of Accounting and Taxation, West Ukrainian National University, Ternopil, Ukraine, ORCID: http://orcid.org/0000-0001-9994-3073

$\triangle$ Corresponding author 